Paedagogia Christiana

I/29 (2012) - ISSN I505-6872

Magdalena Lewicka*

Toruń

\title{
Dialog chrześcijańsko-muzułmański. Klucz do wspólnej przyszłości, Toruń, 19-20 października 2011 roku
}

\begin{abstract}
Dialog międzyreligijny to nie rozmowa przywódców religijnych czy wiernych różnych wyznań; to nie rokowania w stylu dyplomatycznym, to nie teren przetargów, a tym bardziej kompromisów; jego motywacją nie są interesy polityczne czy społeczne; nie ma on na celu podkreślenia różnic ani zamazania ich; nie zmierza do stworzenia globalnej religii, która byłaby do przyjęcia dla wszystkich; nie podejmuje się go jedynie z osobistej inicjatywy ani jako hobby; nie ulega pokusie dwuznaczności pojęć i słów. Prawdziwy dialog to przestrzeń dla wzajemnego świadectwa pomiędzy wiernymi należącymi do odmiennych religii, ażeby poznać bardziej i lepiej religię drugiego oraz postawy etyczne, jakie z niej wypływają. Pozwala to zarazem na skorygowanie błędnych pojęć i przezwyciężenie uprzedzeń i stereotypów, dotyczących osób i społeczności. Chodzi o poznanie drugiego takim, jaki jest, a więc jakim ma prawo być postrzegany, a nie jakim się go przedstawia ani tym bardziej, jakim chce się go widzieć1.
\end{abstract}

Jean-Louis Tauran ${ }^{2}$

* Dr Magdalena Lewicka, arabista i islamolog, kierownik Pracowni Języka i Kultury Arabskiej Uniwersytetu Mikołaja Kopernika w Toruniu.

${ }^{1} \mathrm{Z}$ artykułu na temat zbliżającej się 25. rocznicy historycznego spotkania w mieście św. Franciszka w 1986 roku opublikowanego na łamach „L'Osservatore Romano”. Cytat za: http://www.deon.pl/religia/kosciol-i-swiat/z-zycia-kosciola/art,6246,jaki-jest-sensmiedzyreligijnych-spotkan.html.

2 Jean-Louis Pierre Tauran - francuski duchowny katolicki, dyplomata watykański, kardy- 
Jednym z procesów, a jednocześnie ogromnych wyzwań, kształtujących oblicze XXI wieku, jest dialog między cywilizacjami, którego nieodłącznym elementem jest dialog międzyreligijny. Zarówno przedstawiciele poszczególnych wyznań, jak i ich badacze, są zgodni w opinii, że jest on możliwy i potrzebny, ale wymaga wzajemnego poszanowania, tolerancji i zrozumienia punktu widzenia wszystkich uczestników owego dialogu. Utrudniają go zakorzenione w świadomości ich wyznawców stereotypy dotyczące wzajemnego postrzegania się, które narosły przez lata, a które wciąż wywołują negatywne emocje i stanowią przeszkodę w rewizji poglądów na temat drugiej strony, dodatkowo potęgowane są oskarżeniami o wzajemne krzywdy. Konieczna jest więc akceptacja, okazywanie dobrej woli i autentyczna chęć dialogu opartego na wzajemnym zaufaniu i otwarciu na odmienności, poszanowaniu cudzej tożsamości i integralności, a co za tym idzie - istnieje potrzeba podjęcia działań promujących dialog między przedstawicielami różnych cywilizacji i wyznań oraz współpracę międzynarodową opartą na tolerancji i uznaniu unikalności wkładu różnych kultur i religii w rozwój ludzkości. Działań prowadzących do wzajemnego poznania oraz przezwyciężenia narosłych $\mathrm{z}$ biegiem lat stereotypów i fałszywego wizerunku tych wyznań, tak często funkcjonujących zarówno w przekazach medialnych, jak i świadomości społecznej. Jedną z takich inicjatyw była II Międzynarodowa Konferencja Naukowa Dialog chrześcijańsko-muzutmański. Klucz do wspólnej przyszłości, która odbyła się w dniach 19-20 października 2011 w gmachu Wydziału Filologicznego UMK. Celem przyświecającym spotkaniu naukowców z kraju i zagranicy było przedstawienie historii wzajemnych relacji pomiędzy chrześcijaństwem i islamem oraz analiza zasad konstruktywnego dialogu pomiędzy tymi wyznaniami, ale przede wszystkim - spojrzenie w przyszłość: omówienie wyzwań, jakie stoją przed owym dialogiem u progu XXI wieku.

Konferencja została objęta honorowym patronatem władz miasta i województwa, Marszałka Województwa Kujawsko-Pomorskiego, Piotra Całbeckiego, który podkreślał, że: „Tematyka przedsięwzięcia dotycząca współpracy międzynarodowej opartej na tolerancji dla innych wyznań i poglądów, doskonale wpisuje się w politykę rozwoju województwa prowadzoną przez jego samorząd. Problematyka, której dotyka kampania, jest obecnie bardzo aktualna i wyjątkowo ważna"3 oraz Prezydenta Miasta Torunia, Michała Za-

nał. 25 czerwca 2007 roku został powołany przez papieża Benedykta XVI na przewodniczącego Papieskiej Rady ds. Dialogu Międzyreligijnego, urząd ten objął 1 września tegoż roku.

3 Cytat z pisma Dyrektora Gabinetu Marszałka Województwa Kujawsko-Pomorskiego, Beaty Sawińskiej, skierowanego do sekretarza konferencji, dr Magdaleny Lewickiej, z dnia 20.09.2011 roku. 
leskiego, który wyraził przekonanie, że: „Przedsięwzięcie przyczyni się do propagowania dialogu międzywyznaniowego, prowadzącego do prawdziwego poznania obu religii, wzajemnego szacunku i współdziałania, dzięki któremu będziemy mogli razem sprostać wyzwaniom współczesności"4.

Uczestnicy konferencji, orientaliści, kulturoznawcy, religioznawcy, politolodzy, historycy i reprezentanci innych dyscyplin naukowych związanych z tematyką przewodnią, postawili sobie za cel wymianę doświadczeń i poglądów naukowych badaczy dialogu pomiędzy chrześcijaństwem i islamem, dlatego spotkanie zgromadziło przedstawicieli polskiej i zagranicznej sceny naukowej zajmujących się wzajemnymi relacjami wyznawców obu religii, a także przedstawicieli organizacji muzułmańskich i instytucji zaangażowanych w ów dialog. Gościem honorowym tegorocznego spotkania był ks. prof. dr hab. Waldemar Chrostowski, duchowny rzymskokatolicki (archidiecezja warszawska), profesor zwyczajny i kierownik Katedry Egzegezy Starego Testamentu na Wydziale Teologicznym Uniwersytetu Kardynała Stefana Wyszyńskiego w Warszawie, redaktor naczelny kwartalnika teologów polskich „Collectanea Theologica”, członek Komitetu Nauk Teologicznych Polskiej Akademii Nauk i przewodniczący Stowarzyszenia Biblistów Polskich, autor ponad 2000 publikacji, w tym kilkunastu książek z dziedziny biblistyki i dialogu międzyreligijnego.

W uroczystości otwarcia sympozjum i spotkaniach przewidzianych na pierwszy dzień wydarzenia udział wzięły władze uczelni, miasta i województwa, przedstawiciele środowisk naukowych, a także dyplomaci z krajów arabskich i muzułmańskich w RP. Obrady otworzył kierownik naukowy konferencji, dr hab. Czesław Łapicz, prof. UMK, mówiąc:

Nasze drugie toruńskie spotkanie poświęcone chrześcijańsko-muzułmańskiemu dialogowi odbywa się w bardzo szczególnym czasie i w szczególnym miejscu. Dokładnie 600 lat temu, w 1411 roku na toruńskiej wiślanej wyspie - dawniej i dziś nazywanej Kępą Bazarową - został zawarty traktat pokojowy między Polską i Litwą oraz państwem krzyżackim, znany w historii jako I pokój toruński. Z kolei 19 października 1466 roku, a więc 545 lat temu z dokładnością nawet co do dnia, w którym otwieramy konferencję - zawarto w naszym mieście II pokój toruński. W roku 1645, a więc 366 lat temu, od sierpnia do listopada toczyła się w Toruniu jedna z pierwszych w historii podzielonego chrześcijaństwa „przyjazna rozmowa” luteranów, ewangelików reformowanych, arian (braci czeskich) oraz katolików. Inicjatywa ta jest znana jako „Colloquium

${ }^{4}$ Cytat z pisma Prezydenta Miasta Torunia, Michała Zaleskiego, skierowanego do Dziekana Wydziału Filologicznego UMK, dr hab. Adama Bednarka, prof. UMK, z dnia 16.09.2011 roku. 
Charitativum". Po 350. latach od tego wydarzenia, w roku 1995 przy wspó1pracy Uniwersytetu Mikołaja Kopernika, Towarzystwa Naukowego w Toruniu oraz Kurii Toruńskiej nawiązano do założeń i celów pierwszego Colloquium, organizując odtąd coroczne spotkania znane jako „Colloquia Torunensia”, poświęcone dialogowi międzyreligijnemu i społecznemu. Nic więc dziwnego, że tak w historii, jak i we współczesności Toruń zasłużył sobie na zaszczytne miano Miasta pokoju i dialogu.

Zacytował słowa papieża Jana Pawła II, który w czasie wizyty w Toruniu w roku 1999 powiedział:

Znany jest Toruń z podejmowanych w ciągu historii wysiłków na rzecz pokoju. Tu doszło do dwukrotnego zawarcia traktatów pokojowych, które otrzymały w historii miano Pokoju Toruńskiego. W tym mieście również miało miejsce spotkanie przedstawicieli katolików, luteranów i kalwinistów z całej Europy, które otrzymało nazwę „Colloquium Charitativum”, czyli „Rozmowa Braterska”.

Witając zgromadzonych gości i uczestników konferencji wyraził nadzieję:

Nasze drugie spotkanie poświęcone dialogowi chrześcijańsko-muzułmańskiemu w czasie i w przestrzeni niech stanie się choćby małą cegiełką, służącą budowie wzajemnego zrozumienia i zbliżenia w dobie tak bardzo niepokojących i niebezpiecznych napięć nie tylko społecznych i politycznych, ale także religijnych. Niech ponad czasem i ponad przestrzenią, ponad polityką, kulturą i ideologią, spełni się życzenie błogosławionego Jana Pawła II, aby słowa religii byty zawsze stowami pokoju.

Do hasła „Toruń miastem pokoju”, pod którym upływa bieżący rok w grodzie Kopernika, bowiem pozostaje on miejscem wielkich historycznych wydarzeń, jak choćby obrad sejmu w XVI i XVII wieku, wizyt władców, a także miastem dialogu międzykulturowego oraz pokojowej wymiany poglądów, o czym świadczą właśnie oba pokoje toruńskie czy „Colloquium Charitativum”, nawiązywali także kolejni mówcy: występujący w imieniu Marszałka Województwa Kujawsko-Pomorskiego Sławomir Kopyść i Wiceprezydent Miasta Torunia, Ludwik Szuba. Ten ostatni odczytał list Prezydenta Michała Zaleskiego, zaczynający się słowami:

Serdecznie pozdrawiam wszystkich, którzy przejęci potrzebą szukania przyjaźni i porozumienia pomiędzy ludźmi różnych społeczności dotarli do Torunia na debatę o dialogu chrześcijańsko-muzułmańskim. Dziękuję za obecność reprezentantom przedstawicielstw dyplomatycznych, związków wyznaniowych 
oraz polskich i zagranicznych ośrodków naukowych. Państwa spotkanie potwierdza często przywoływaną opinię, że Toruń był przed wiekami i wciąż jest miastem dialogu wyznaniowego. Nadzieja na jego skuteczność i celowość jest dziś w każdym z nas.

Po przedstawicielach uczelni, miasta i województwa głos zabrał J.E. Ambasador Algierii w RP i zarazem Dziekan Ambasadorów Państw Muzułmańskich akredytowanych w Polsce, Abdelkader Khemri, który zauważył, że:

Islam jest jedną z trzech największych, obok chrześcijaństwa i judaizmu, religii monoteistycznych, a także kluczowym elementem w wysiłkach ludzkości, podejmowanych od przełomu XX i XXI wieku, określanych mianem dialogu pomiędzy religiami i cywilizacjami. Analiza tych zagadnień, mimo świadomości, iż wymagają one wkładu ogromnego wysiłku, pozwala dostrzec prawdę dotyczącą ludzkiego istnienia, dla którego fundamentem jest dobro, miłość i poświęcenie na rzecz obrony prawdy i wartości stanowiących podstawy współżycia i współistnienia w pokoju, zrozumieniu, tolerancji i akceptacji drugiego człowieka, przy jednoczesnym odpieraniu wszelkich przejawów zła, jakimi są przemoc, rasizm i agresja. Społeczność muzułmańska, a wraz z nią najwybitniejsi naukowcy i intelektualiści zdali sobie sprawę z faktu, że walka ta, walka pokojowego współistnienia i dialogu jest jedynym sposobem przezwyciężenia niesprawiedliwości i wszelkich form alienacji, a celem, na rzecz którego podejmuje poważne wysiłki, jest stworzenie przestrzeni dla dialogu między religiami i cywilizacjami jako mechanizmów prowadzących do porozumienia i rozwoju.

Pierwszej części obrad, która wprowadziła uczestników spotkania w tematykę metodologicznych i merytorycznych aspektów dialogu chrześcijańsko-muzułmańskiego, przewodniczył dr Artur Konopacki (Rada Wspólna Katolików i Muzułmanów, Uniwersytet w Białymstoku). Pytania o sens i sposób prowadzenia tegoż dialogu stawiał zebranym prof. dr hab. Bassam Aouil (Uniwersytet Kazimierza Wielkiego). Wskazał:

Dialog to piękne słowo i szczytna koncepcja, którą należy rozpatrywać w dwóch kategoriach: dialog jako proces i dialog jako rezultat. Niezależnie od kategorii wymaga on zawsze obecności dwóch stron, posiadających chęć i podstawy umożliwiające dojście do porozumienia w zasadniczych kwestiach celem znalezienia alternatywnych rozwiązań dotyczących ich problemów, rozwiązań korzystnych dla obu stron i reprezentowanych przez nie społeczności.

Dodał także, iż problem ten jest szczególnie ważny „w obliczu rosnącej obecności muzułmanów, która zmienia sytuację historyczną, kulturową i religijną 
Europy, zdominowanej jeszcze do niedawna przez chrześcijaństwo". Kolejny prelegent, współprzewodniczący Rady Wspólnej Katolików i Muzułmanów, ks. dr Adam Wąs (Katolicki Uniwersytet Lubelski), scharakteryzował pod kątem treści i znaczenia dla dialogu chrześcijańsko-muzułmańskiego orędzia przesyłane muzułmanom od 1967 roku w imieniu papieża i całego Kościoła rzymskokatolickiego z okazji święta Id al-Fitr, które wyznawcy islamu obchodzą na zakończenie postu w miesiącu ramadan. Jak zauważył:

Stanowią one ważny element realizacji soborowych postanowień Kościoła rzymskokatolickiego, wyrażając jego otwartość i dialogową postawę wobec wyznawców islamu. Potwierdzają dobre stosunki między chrześcijanami i muzułmanami oraz pomagają im we wzajemnym zrozumieniu. Coroczne przesłanie motywuje wyznawców obu religii do podtrzymywania istniejących kontaktów i inspiruje do nawiązywania nowych na płaszczyźnie oficjalnej i prywatnej. Bez wątpienia jest ono okazją do wspólnej refleksji i wspólnych działań podejmowanych dla wspólnego dobra.

Tematem wystąpienia dr Aldony Marii Piwko (Uniwersytet Kardynała Stefana Wyszyńskiego) była Modlitwa, post, jałmużna - chrześcijańskie i muzułmańskie drogowskazy do wspólnej przyszłości. Jej zdaniem

modlitwa w obu religiach stanowi szczególny wyraz oddania się Bogu, a zarazem jest jedną z podstawowych form sprawowania kultu. Post jest podjęciem przez słabego człowieka wysiłku, aby przemieniać siebie, a tym samym zbliżać się do Boga. Jałmużna jest uczynkiem miłosierdzia względem biednych i potrzebujących. W obu religiach posiada podobne znaczenie oraz wydźwięk. Pozwala człowiekowi, z natury samolubnemu, otworzyć serce na bliźnich, a przede wszystkim dostrzec i pochylić się nad ubogimi. Islam nakłada obowiązek na wiernych dzielenia się swoim majątkiem.

Warto zacytować także słowa, którymi zakończyła swój referat:

Te trzy płaszczyzny stanowią fundamenty wspólnego działania chrześcijan i muzułmanów ku lepszej przyszłości. Modlitwą i postem wypraszać u dobrego Boga łaskawość oraz pokój dla grzesznego świata, zaś jałmużną wspierać potrzebujących. Podejmowanie współpracy, zgodnej z zasadami moralnymi własnej religii, przyniesie przemianę wielu społeczeństw. Człowiek XXI wieku coraz częściej jest niewrażliwym egoistą, który stał się takim przez brak życia religijnego. Dlatego potrzebuje żywych wzorów, aby mógł się zmienić. 
Ostatni referat sesji otwierającej wygłosił dr hab. Selim Chazbijewicz, prof. UWM (Uniwersytet Warmińsko-Mazurski), który poruszył zagadnienie dialogu chrześcijańsko-muzułmańskiego w Polsce w kontekście sytuacji dialogicznej w Rosji, na Białorusi i Ukrainie. Zaznaczył, że: „Dialog chrześcijańsko-muzułmański w Polsce ma wieloletnią, a nawet wielowiekową tradycję, która wynika z 600 lat pokojowego współistnienia chrześcijaństwa i islamu na ziemiach Rzeczypospolitej”, a następnie omówił historię i działalność Tatarów - muzułmanów we współczesnej Polsce.

Tematem sesji drugiej, moderowanej przez prof. dr. hab. Bassama Aouila (UKW), byli orędownicy międzyreligijnego dialogu. W tej części spotkania znalazły się wystąpienia dr. Michała Mocha (Uniwersytet Kazimierza Wielkiego), Sercem szukamy jedności. Matta al-Miskin - wybitny myśliciel, teolog i orędownik dialogu, dr Magdaleny Lewickiej (Uniwersytet Mikołaja Kopernika), Między teoria a praktyka - Gülenowski model dialogu międzywyznaniowego i mgr. SelËuka Õzcana (Dunaj Instytut Dialogu), Wkład ruchu Fetullaha Gülena w rozwój dialogu chrześcijańsko-muzutmańskiego $w$ Turcji. Pierwszy mówca zaprezentował sylwetkę koptyjskiego mnicha, teologa i intelektualisty, Matty ăl-Miskīna, który ,stworzył bardzo ciekawy nurt intelektualny we współczesnym chrześcijaństwie egipskim”,

określał się jako bardzo zdecydowany zwolennik dążenia do jedności chrześcijan. Jest to jednak teologia dość mocno odbiegająca od nauczania patriarchy Šanūdy III, jak również od współczesnego nurtu ekumenicznego czy też oficjalnego ruchu dialogu międzyreligijnego. Najważniejszą rolę odgrywa tu bowiem bezpośredni kontakt z Bogiem, dopiero po zbudowaniu relacji ze Stworzycielem, polegającej na osiągnięciu jedności, możliwe jest wyjście do drugiego człowieka. Tak rozumiana jedność umożliwia pokonanie podziałów o charakterze historycznym.

Celem dwóch kolejnych referentów było przedstawienie idei dialogu w ujęciu wpływowego intelektualisty tureckiego i uczonego muzułmańskiego, Fethullaha Gülena, zdaniem którego: „Dialog międzyreligijny jest w dzisiejszych czasach koniecznością, a pierwszym krokiem w kierunku nawiązania tegoż dialogu jest puszczenie w niepamięć przeszłości i odrzucenie argumentów prowadzących do polemiki na rzecz punktów wspólnych, których jest znacznie więcej niż powodów do spornych dyskusji”.

W popołudniowej części programu konferencji znalazło się spotkanie z podróżnikiem dr Zdzisławem Preisnerem (Wyższa Szkoła Gospodarki), Stambut - dwa tysiace lat świetności, prezentujące najcenniejsze dzieła architektoniczne położonego na dwóch kontynentach: Azji i Europie, uważanego za jedno z najpiękniejszych i najciekawszych miast na ziemi, Stambu- 
łu - uwiecznione na fotografiach wykonanych przez autora. Wydarzeniem zamykającym pierwszy dzień obrad, a jednocześnie nawiązującym do tematyki przewodniej naukowego spotkania, był koncert w wykonaniu Camerata Vladislavia dedykowany pamięci Jana Pawła II jako orędownika dialogu międzyreligijnego, który zgromadził miłośników muzyki poważnej w Sali Złotej Pałacu Dąmbskich.

Na kolejny dzień konferencji złożyły się dwie sesje, z których pierwszą, prowadzoną przez doc. Michaiła Tarełkę (Białoruski Uniwersytet Państwowy), otworzył referat ks. prof. dr. hab. Waldemara Chrostowskiego (Uniwersytet Kardynała Stefana Wyszyńskiego), wprowadzający zebranych w zasady dialogu międzyreligijnego z perspektywy katolickiej. Przypomniał on momenty przełomowe $\mathrm{w}$ dialogu chrześcijańsko-muzułmańskim: obrady Soboru Watykańskiego II, których pokłosiem była Deklaracji o stosunku Kościoła do religii niechrześcijańskich Nostra aetate z najbardziej znanym jej fragmentem:

Kościół spogląda z szacunkiem również na muzułmanów, czcicieli jedynego Boga, żyjącego i samoistnego, miłosiernego i wszechmocnego, Stworzyciela nieba i ziemi, który przemówił do ludzi. Starają się również poddawać z całej duszy Jego ukrytym postanowieniom, tak jak poddał się Bogu Abraham, do którego islamska wiara chętnie się odwołuje. Jezusa wprawdzie nie uznają za Boga, czczą Go jednak jako proroka a Jego dziewiczą matkę, Maryję, darzą szacunkiem i niekiedy pobożnie Ją wzywają. Oczekują nadto dnia sądu, kiedy Bóg odda zapłatę wszystkim wskrzeszonym ludziom. Dlatego też cenią życie moralne i czczą Boga szczególnie przez modlitwę, jałmużnę i post ${ }^{5}$

oraz dokonania Jana Pawła II, którego wezwanie do okazywania szacunku islamowi i jego wyznawcom, popierane niezwykle często jego własnym przykładem i świadectwem, a zauważane i doceniane przez muzułmanów nie tylko w Polsce, dają mu trwałe miejsce w historii cywilizacji. Problematykę islamu na Krymie przybliżył dr hab. Kazimierz Banek, prof. UJ (Uniwersytet Jagielloński) wskazując, iż

w ciągu około 3 tysięcy lat przez Krym przewinęło się wiele ludów: Kimmeriowie, Taurowie, Meotowie, Scytowie, Grecy, Sarmaci, Rzymianie, Goci, Krymczaki, Bizantyjczycy, Chazarowie, Żydzi, Karaimi, Protobułgarzy, Połowcy, Pieczyngowie, Słowianie, Ormianie, Tatarzy, Włosi, Turcy, Rosjanie i Ukraińcy, a także Serbowie, Grecy, Albańczycy, Niemcy, Polacy, Bułgarzy, Czesi

5 Pełny tekst Deklaracji o stosunku Kościoła do religii niechrześcijańskich Nostra aetate patrz: Sobór Watykański II. Konstytucje, dekrety i deklaracje, Poznań 2002. 
i Estończycy. Nacje te w różnym stopniu wpłynęły na dzieje półwyspu i jego kulturę.

Mgr Hanna Szczerbak natomiast w wystąpieniu Wizerunek świata arabskiego w sztuce i kulturze europejskiej XX wieku jako klucz do zrozumienia relacji między światem muzutmańskim a chrześcijańskim skupiła się na problematyce odbioru świata tak zwanego Orientu przez świat kultury europejskiej przez pryzmat sztuk plastycznych i filmu, ponieważ jej zdaniem:

zastanowienia wymagają powody takiego, a nie innego postrzegania świata Orientu w świadomości Europejczyków, gdyż, przyjmując za znaną pracą Edwarda Wadiego Saida, samo pojęcie „Orientu” było pewnego rodzaju mitem, choć nie zawsze pozytywnym. Tym samym interesujące jest również zestawienie takiego XIX-wiecznego postrzegania Bliskiego Wschodu w kulturze ze spojrzeniem ostatnich pięćdziesięciu lat, na co z całą pewnością miały ogromny wpływ przemiany społeczne w państwach europejskich, powiązane w ogromnym wzrostem imigrantów, jak również wydarzenia polityczne ostatnich lat i nasilające się tendencje fundamentalistyczne.

W tematykę przenikania religijnego muzułmańsko-chrześcijańskiego wprowadził uczestników konferencji dr Artur Konopacki (Uniwersytet w Białymstoku), współprzewodniczący Rady Wspólnej Katolików i Muzułmanów, który scharakteryzował środowisko wyznawców islamu w Rzeczypospolitej Obojga Narodów. Jak zauważył:

Przybywający osadnicy byli muzułmanami - sunnitami - i jako dobrowolni osiedleńcy mieli prawo do zachowania swego wyznania. Ponadto objęci ochroną hospodara wznosili swoje świątynie, zakładali cmentarze. Funkcjonując w otoczeniu chrześcijańskim podlegali jednak zjawisku dyfuzji kulturowej. Przejmowali pewne zachowania, zwyczaje ludności miejscowej (chrześcijańskiej) do apostazji włącznie.

Wymianie poglądów i doświadczeń związanych z badaniami nad różnymi aspektami dialogu międzyreligijnego w piśmiennictwie Tatarów polskolitewskich służyła ostatnia sesja, Muzułmanie wśród chrześcijan w Wielkim Księstwie Litewskim, moderowana przez ks. prof. dr. hab. Waldemara Chrostowskiego. Swoje referaty przedstawili referenci z zagranicy: doc. Michaił Tarełka (Białoruski Uniwersytet Państwowy) i dr Irina Synkowa (Miński Instytut Kierowania) oraz dr hab. Czesław Łapicz, prof. UMK (Uniwersytet Mikołaja Kopernika). Doc. Tarełka, zaczynając wystąpienie od stwierdzenia, że „spuścizna rękopiśmienna Tatarów Białoruskich jest nieskończonym 
źródłem tekstów, będących produktem dialogu chrześcijańsko-muzułmańskiego", dokonał analizy pojawiającego się w części XIX- i XX-wiecznych kitabów, nieopublikowanego dotąd utworu zaczynającego się od słów „Kiedy Pana Jezusa męczono...", które można przyjąć jako umowny jego tytuł. Jak zauważył: „Za kluczowe zdanie, które zawiera istotę tego utworu, uważać można następującą wypowiedź: „Gdy zapytają czy Jezus lepszy czy Muhammad...", z zasługującą na uwagę dalszą treścią:

Odpowiedź: „Obydwaj prorocy - miłośnicy Pańskie, ale Emmanuel lepszy”, a następnie dodał: „Oczywistym, jest, że taki tekst muzułmański, którego autor stara się udowodnić związek między Prorokiem islamu - Muhammadem a Pismem biblijnym, mógł powstać tylko w wyniku dialogu między światem muzułmańskim a chrześcijańskim.

Dr Synkova natomiast, po podkreśleniu, że „w pamiętnikach tej literatury odzwierciedliły się różne aspekty dialogu międzyreligijnego (jak i części dialogu międzykulturowego)", sięgnęła do tekstów zamawiań, które można znaleźć w rękopisach tatarskich, przy czym wiele z nich wykazuje wyraźny wpływ chrześcijański. Swój referat podsumowała stwierdzeniem: „Dyfuzja pojęć w sferze znachorstwa (jak i części kultury narodowej) wskazuje, w jaki sposób w granicznym obszarze międzyreligijnym powstaje pole wyobrażeń ogólnych, swoistego chrzyslamu, którego idee pozbawione są obciążenia teologicznego i bazują zwykle na ogólnoludzkich wartościach i zasadach moralnych". Referatem zamykającym obrady było wystąpienie dr. hab. Czesława Łapicza, prof. UMK, który omówił specyfikę międzyreligijnych dysput, zwłaszcza chrześcijańsko-muzułmańskich, prowadzonych w wielowyznaniowym i wielokulturowym Wielkim Księstwie Litewskim z podkreśleniem współczesnego rozumienia międzyreligijnego dialogu oraz praktykowania go w relacjach chrześcijańsko-muzułmańskich. Jak zauważył:

Z różnych powodów dysputy te charakteryzowały się niską kompetencją merytoryczno-teologiczną, natomiast $\mathrm{w}$ większym stopniu uwzględniały czynniki pozareligijne, $\mathrm{w}$ tym także obyczajowe, często przeradzając się $\mathrm{w}$ słowne polemiki i kłótnie. Ślady dysput zachowały się do dzisiaj w piśmiennictwie religijnym muzułmanów litewsko-polskich oraz w reformacyjnej i kontrreformacyjnej literaturze antyislamistycznej.

Ostatnim etapem było podsumowanie konferencji, którego dokonał ks. prof. dr hab. Waldemar Chrostowski, analizując i komentując zarówno przedstawione przez referentów wykłady, jak i dyskusje, będące zwieńcze- 
niem kolejnych części obrad. Na zakończenie naukowego spotkania zacytował słynną maksymę, która w doskonały sposób obrazuje postawę niezbędną do podejmowania i prowadzenia dialogu: ,Jeżeli ja to jestem ja, bo ty to jesteś ty, to ani ja nie jestem ja, ani ty nie jesteś ty. Ale jeżeli ja to jestem ja, bo ja to jestem ja, a ty to jesteś ty, bo ty to jesteś ty, to wtedy ja to jestem ja, a ty to jesteś ty - i możemy rozmawiać" .

Organizatorzy konferencji wyrazili nadzieję, że tegoroczna edycja wzorem ubiegłorocznej znajdzie kontynuację w postaci kolejnych spotkań, które odbywać się będą w październiku każdego roku i wpiszą się na stałe w kalendarz naukowo-kulturalnych wydarzeń Torunia, podobnie jak jesienne debaty międzyreligijne Colloquia Torunensia. Zwłaszcza, że - jak ujął to prof. dr hab. Andrzej Radzimiński, rektor UMK:

Współistnienie islamu i chrześcijaństwa to jeden z czynników, który ma najistotniejszy wpływ na kształtowanie współczesnego świata. Niestety, wśród niezliczonych doniesień skupiających się na konfrontacyjnym wymiarze wzajemnych kontaktów, tak rzadko mówi się o tym, co łączy i stanowi wspólne dziedzictwo. Tymczasem pobieżna choćby znajomość historii Europy, w tym i naszego kraju, pokazuje niezaprzeczalne wartości wniesione przez współistnienie naszych kultur, udowadnia, że przypadki konfliktów i nieporozumień są być może atrakcyjne medialnie, lecz nie odpowiadają rzeczywistemu charakterowi tego współistnienia. Stąd tak ważne inicjatywy, które pozwalają przywrócić prawidłowe proporcje w postrzeganiu stosunków chrześcijańsko-muzułmańskich. Szczególnie istotne jest, że toruńskie spotkanie nie poprzestaje jedynie na przypominaniu przeszłości, lecz chce zbudować na jej lekcji przesłanie na przyszłość 7 .

6 Autorem maksymy jest rabin Menachem Mendel Morgenstern z Kocka (1787$-1859)$.

${ }^{7}$ Fragment przemówienia wygłoszonego podczas inauguracji konferencji. 